\title{
EXPERIMENTAL SUBSTANTIATION OF THE IMMUNOSTIMULATING EFFECT OF BRANCHED-CHAIN AMINO ACIDS UNDER STRESS
}

\author{
E.N. Trushina ${ }^{1}$, A.N. Timonin ${ }^{1}$, N.A. Ryger ${ }^{1}$, O.K. Mustafina ${ }^{1}$, V.D. Kuznetsov ${ }^{2}$ \\ ${ }^{1}$ Federal Research Centre of Nutrition, Biotechnology and Food Safety, Moscow, Russia; \\ ${ }^{2}$ First Moscow State Medical University named after I.M. Sechenov, Moscow, Russia

\section{ЭКСПЕРИМЕНТАЛЬНОЕ ОБОСНОВАНИЕ ИММУНОСТИМУЛИРУЮЩЕГО ЭФФЕКТА АМИНОКИСЛОТ С РАЗВЕТВЛЕННОЙ ЦЕПОЧКОЙ МОЛЕКУЛЫ В УСЛОВИЯХ СТРЕССА}

\author{
Э.Н. Трушина ${ }^{1}$, А.Н. Тимонин ${ }^{1}$, Н.А. Ригер ${ }^{1}$, О.К. Мустафина ${ }^{1}$, В.Д. Кузнецов ${ }^{2}$ \\ ${ }^{1}$ ФГБУН «ФИЦ питания и биотехнологии», Москва; \\ ${ }^{2}$ Первый московский государственный медицинский университет им. И.М. Сеченова, Москва
}

\begin{abstract}
The aim is to study the effect of branched-chain amino acid (BCAA) on cytokine synthesis in male Wistar rats on the background of cyclic starvation. A study of 2 months duration was performed on 60 rats, which were divided into 3 groups ( 20 rats in each group): rats of the control group (K-group) received standardized balanced laboratory feed for rodents ad libitum. The animals of the $1^{\text {st }}$ experimental group $(\mathrm{O}-1$ group $)$ were fed according to the following scheme: the first day - feed ad libitum, the second and the third day - fasting, the rats of the $2^{\text {nd }}$ experimental group (O-2 group) were given feed according to the same scheme, but with the addition of BCAA at a dosage of $70 \mathrm{mg} / \mathrm{kg}$ body weight per day. In the serum of rats, cytokine levels were determined: GM-CSF, INF- $\gamma$, IL-10, IL-12p70, IL-13, IL-1 $\alpha$, IL-1 $\beta$, IL-2, IL-4, IL-5, IL- 6, TNF- $\alpha$ on the Luminex 200 multiplex analyzer (Luminex Corporation, USA). Statistical processing of the results was performed using the IBM SPSS Statistics Version 20.0 application package ("IBM", USA). As a result of the study, it was established that the consumption of BCAA by rats for 2 months on the background of cyclic starvation causes a decrease in the level of IL-10 and an increase in serum levels of IL-1a and IL-2 due to the activation of signaling pathways that regulate switching of the Th2 immune response to the predominant production of Th1 cytokines.
\end{abstract}

Keywords: branched chain amino acids (BCAA); cyclic starvation; cytokines.

Целью исследования явилось изучение влияния аминокислот с разветвленной цепочкой молекулы (branched-chain amino acids - BCAA) на синтез цитокинов у крыс-самцов линии Вистар на фоне циклического голодания. Исследование длительностью 2 месяца выполнено на 60 крысах, которые были разделены на 3 группы (по 20 крыс в каждой группе): крысы контрольной группы (К-группа) получали стандартизованный сбалансированный лабораторный корм для грызунов ad libitum. Животным 1-ой опытной группы (O-1 группа) корм давали по схеме: первые сутки - корм ad libitum, вторые и третьи сутки - голодание, крысам 2-й опытной группы (O-2 группа) корм давали по этой же схеме, но с добавлением ВСАА в дозировке 70 мг/кг массы тела в сутки. В сыворотке крови крыс определяли уровня цитокинов: GM-CSF, INF- $\gamma$, IL-10, IL-12p70, IL-13, IL-1 $\alpha$, IL-1 $\beta$, IL-2, IL-4, IL-5, IL-6, TNF- $\alpha$ на мультиплексном анализаторе «Luminex 200» («Luminex Corporation», CША). Статистическую обработку результатов проводили с использованием пакета прикладных программ IBM SPSS Statistics Version 20.0 («IBM», США). В результате исследования установлено, что потребление крысами ВСАА в течение 2-х месяцев на фоне циклического голодания вызывает снижение уровня IL-10 и возрастание уровней IL-1a и IL-2 в сыворотке крови за счет активации сигнальных путей, регулирующих переключение Th2-иммунного ответа на преимущественную продукцию цитокинов Th1.

Ключевые слова: аминокислоты с разветвленной цепочкой молекулы (BCAА); циклическое голодание; цитокины.

The immune system, as one of the key integral and regulatory systems of the body, is most sensitive to stress factors that may be due to starvation, emotional, mental and physical overstrain. The need for branched-chain amino acid (BCAA): valine, leucine, isoleucine for the functioning of immune system cells is determined primarily by their participation in protein biosynthesis.
The aim is to study the effect of BCAAs on cytokine synthesis in male Wistar rats on the background of cyclic starvation.

Materials and methods. A study of 2 months duration was performed on 60 rats, which were divided into 3 groups (20 rats in each group): rats of the control group (K-group) received standardized balanced laboratory feed for rodents ad libi- 
Cytokine level $(\mathrm{pg} / \mathrm{ml})$ in male Wistar rats (Mean $\pm \mathrm{SD})$

\begin{tabular}{|l|c|c|c|}
\hline \multicolumn{1}{|c|}{ Variable } & K-group & O-1 group & O-2 group \\
\hline GM-CSF & $0.130 \pm 0.083$ & $0.120 \pm 0.078$ & $0.110 \pm 0.083$ \\
\hline IFN- $\gamma$ & $0.220 \pm 0.131$ & $0.230 \pm 0.084$ & $0.200 \pm 0.117$ \\
\hline IL-10 & $0.270 \pm 0.119$ & $0.260 \pm 0.116$ & $0.210 \pm 0.087^{* *}(*)$ \\
\hline IL-12 (p70) & $1.560 \pm 0.423$ & $1.790 \pm 0.801$ & $1.390 \pm 0.745$ \\
\hline IL-13 & $0.640 \pm 0.171$ & $0.650 \pm 0.525$ & $0.640 \pm 0.441$ \\
\hline IL-1a & $0.240 \pm 0.091$ & $0.250 \pm 0.062$ & $0.290 \pm 0.103^{*}$ \\
\hline IL-1b & $0.180 \pm 0.119$ & $0.220 \pm 0.166$ & $0.180 \pm 0.119$ \\
\hline IL-2 & $4.370 \pm 1.843$ & $3.230 \pm 0.678^{*}$ & $3.660 \pm 1.962$ \\
\hline IL-4 & $0.090 \pm 0.038$ & $0.090 \pm 0.035$ & $0.090 \pm 0.057$ \\
\hline IL-5 & $6.310 \pm 2.041$ & $5.350 \pm 1.762$ & $5.400 \pm 1.861$ \\
\hline IL-6 & $1.420 \pm 0.581$ & $1.570 \pm 0.539$ & $1.390 \pm 0.549$ \\
\hline TNF- $\alpha$ & $0.740 \pm 0.272$ & $0.750 \pm 0.429$ & $0.790 \pm 0.312$ \\
\hline
\end{tabular}

N o t e. A statistical comparison was made by student's $t$ test; ${ }^{*} p<0.05$ vs K-group; ${ }^{* *} p<0.05 \mathrm{O}-1$ group vs O-2 group.

tum. The animals of the $1^{\text {st }}$ experimental group (O-1 group) were fed according to the following scheme: the first day - feed ad libitum, the second and the third day - fasting, the rats of the $2^{\text {nd }}$ experimental group $(\mathrm{O}-2$ group $)$ were given feed according to the same scheme, but with the addition of BCAA at a dosage of $70 \mathrm{mg} / \mathrm{kg}$ body weight per day. In the serum of rats, cytokine levels were determined: GM-CSF, INF- $\gamma$, IL-10, IL-12p70, IL-13, IL-1 $\alpha$, IL-1 $\beta$, IL-2, IL-4, IL-5, IL- 6, TNF- $\alpha$ on the Luminex 200 multiplex analyzer (Luminex Corporation, USA). Statistical processing of the results was performed using the IBM SPSS Statistics Version 20.0 application package ("IBM", USA).

Results and discussion. The results of the study of the effect of BCAA on the cytokine profile of rats under cyclic starvation are presented in Table 1.

When assessing changes in the cytokine profile of Th1/Th2, there were no statistically significant differences for most of the studied parameters (Table 1). Changes were found only in the IL-10 level between the experimental and control groups, in the IL-1a level between the control and the O-2 group (BCAA), and in the IL-2 level between the control and the O-1 group.

Cyclic starvation (O-1 group) had small effect on the content of IL-10 in the blood serum of animals. Consumption of BCAA in rats contributed to a significant decrease in the level of IL-10 compared with the control and the O-1 group. Fasting also did not significantly affect the level of IL-1a. But the addition of BCAA to the diet caused a statistically significant increase in serum cytokine levels in rats in the O-2 group. Cyclic star- vation of rats (O-1 group) resulted in a statistically significant decrease in serum IL-2 levels compared to controls. The addition of BCAA to the diet of animals contributed to an increase at the trend level $(p<0.10)$ of the value of this indicator compared with the O-1 group in the absence of significant differences with the control.

It is well known that the lack of macro- and micronutrients during fasting causes hypotrophy of lymphoid tissue. This means a decrease in the number of circulating lymphocytes, which is a consequence of the inhibition of DNA synthesis and cell proliferation. Humoral and cellular immunity is reduced by reducing the cell population of antibody-producing cells and T-lymphocytes, and the immunoregulatory index $\mathrm{CD} 4^{+} / \mathrm{CD}^{+}$decreases, which indicates the development of immunosuppression $[2,3]$. Under fasting conditions, the addition of BCAA to the diet has a certain immunotropic effect due to the effect on the synthesis of proteins, RNA and DNA. BCAAs are involved in the metabolism of almost all cells involved in the regulation of the immune response $[1,6]$. Increasing the level of BCAA, the induction of oxidative processes in cells, causes activation of the mTOR signaling pathway and contributes to a decrease in the level of TGF- $\beta$, IL-6, and IL-10 [5]. This mechanism may explain the decrease in the level of IL-10 when BCAA is added to the ration of rats compared with the control and the group of rats that did not receive a mixture of amino acids. Against this background, the activation of signaling pathways contributes to the switching of the Th2 immune response to the predominant production of Th1 cytokines and the suppression of Treg cells $[4,6]$. The result is an increase in the level of IL-1a 
and the restoration of the content of IL-2 in the O-2 group of animals.

Conclusion. The consumption of BCAA by rats for 2 months on the background of cyclic starvation causes a decrease in the level of
IL-10 and an increase in serum levels of IL-1a and IL-2 due to the activation of signaling pathways that regulate switching of the Th2 immune response to the predominant production of Th1 cytokines.

\section{References}

1. Calder PC. Branched-Chain Amino Acids and Immunity. The Journal of Nutrition. 2006;136(1):288S$293 \mathrm{~S}$.

2. Catherine GR Jackson. Nutrition and the Strength Athlete. Health \& Fitness. 2000; ISBN-0-84938198-3:175-192.

3. Chandra RK. 1990. McCollum Award lecture. Nutrition and immunity: lessons from the past and new insights into the future. Am. J. Clin. Nutr. 1991;53:1087-1101.

4. Bassit RA, Sawada LA, Bacurau RFP, et al. Branched chain amino acid supplementation and the immune response of long-distance athletes. Nutrition. 2002;18:376-379.

5. Khedr NF, Khedr EG. Branched chain amino acids supplementation modulates TGF- $\beta 1 /$ Smad signaling pathway and interleukins in CCl4-induced liver fibrosis. Fundam. Clin. Pharmacol. 2017;31:534-545.

6. Monirujjaman Md, Ferdouse A. Metabolic and Physiological Roles of Branched-Chain Amino Acids. Advances in Molecular Biology. 2014;Article ID 364976 http://dx.doi.org/10.1155/2014/364976. 